\title{
Low Cost Robotic Manipulator for Family Agriculture
}

\author{
Marcia Regina Maboni Hoppen Porsch \\ UERGS - State University of Rio Grande do Sul, Av. Fiorentinho Bacchi, 311, Center, \\ 99840.000, Sananduva - Brazil \\ Phone: +55 (54) 33433241 E-mail: marcia.porsch@hotmail.com
}

Luiz Antonio Rasia (Corresponding author)

DCEEng -Exact Sciences and Engineering Department, UNIJUI - Regional University of the Northwest of Rio

Grande do Sul, Street Lulu Ingelfritz, 480 São Geraldo, 99700.000, Ijuí -Brazil

Phone: +55(55)33320200 E-mail: rasia@unijui.edu.br

\section{Nelson José Thesing}

Department of Administrative, Accounting, Economic and Communication Sciences, UNIJUI - Regional University of the Northwest of Rio

Grande do Sul, Street of Comércio 3000, Universitário, 98700.000, Ijuí - Brazil

E-mail: Nelson.thesing@unijui.edu.br

\section{Patricia Carolina Pedrali}

DCEEng -Exact Sciences and Engineering Department, UNIJUI - Regional University of the Northwest of Rio

Grande do Sul, Street Prefeito Rudi Franke, No 540, Arco Iris, 98280000, Panambi - Brazil

E-mail: patricia.pedrali@unijui.edu.br

\section{Antonio Carlos Valdiero}

UFG - Goias Federal University, FENG - Engineering College, Street Geraldo Belo da Silva, No 121-177, 75705220, Catalão - GO-Brazil

E-mail: antoniocvaldiero@gmail.com 
Received: Sep. 1, 2019

doi:10.5296/jas.v7i4.15369
Accepted: Sep. 25, 2019

Published: Sep. 28, 2019

URL: https://doi.org/10.5296/jas.v7i4.15369

\begin{abstract}
This article introduces or designs and practices a Gantry pneumatic robotic manipulator for greenhouse automation. The prototype was built on the reduced model for sowing and harvesting vegetables using the familiar concept of agriculture. Low-cost robotic handlers can contribute to improved working conditions in family farming and enable strategies to diversify agricultural activities for low-income families. The system has two degrees of freedom, was mounted on a metal workbench using cylinders and specially manufactured guided cable actuator. The control system includes nonlinear compensations of the servo valves used. Functional tests used step input electrical signals $(-4 \mathrm{~V}$ to $+4 \mathrm{~V}$ and $-8 \mathrm{~V}$ to $+8 \mathrm{~V})$ using open loop circuit for robot pressure and positioning control. The results obtained are important for perfecting the robotic manipulator for family farming applications.
\end{abstract}

Keywords: gantry robot, pneumatic drive, automatic control, precision farming

\title{
1. Introduction
}

In recent years the development of precision agricultural machines incorporating robotics knowledge has experienced an increase in research investment, (Auat and Carelli, 2013).

The presence of low cost robotic handlers in rural areas can contribute significantly to the search for better working conditions in family farming. In this context, the Brazilian and world reality are undergoing rapid and successive changes, an intensification of competition that indicate new challenges, a concept that emerges in Brazil in the 1990s.

This process marks the recognition of a social category of rural workers, within the scope of public policies, by providing resources for funding and investments, creation of municipal, state, national rural development councils, as well as a set of research lines, giving conditions for pluriactivity, a new rural reality. This concept allows the occupation of spaces in the agricultural as well as in the industrial, commerce and service areas according to (Escher, et al., 2014).

The application of agricultural machinery involving the concept of precision agriculture has experienced increased investment and research in recent years due to the use of robotic applications in machine design and autonomous machine tasks, operation, guidance and control to perform precision agricultural tasks (Cheein \& Carelli, 2013). (Eaton et al., 2008) argue about the necessary integration of requirements, combining the areas of robotics with autonomous agriculture and precision agriculture, which deals with agronomic issues. For (Amer et al., 2015), robotics in agriculture is not a new concept, already has a history of 20 years of research in the development of harvesters for cherry tomatoes, cucumbers, mushrooms and others.

Advances in research relating robotics and precision agriculture can be observed in the work 
of (Yang et al., 2016) developed based on omnidirectional vision system a human detection system integrated with a robot tractor to monitor its surroundings, with purpose provide a safer environment.

In this work, the research and development of a reduced model gantry robot with pneumatic actuators for greenhouse application and for the automation of vegetable production enables to diversify production, reduce lace instability and seasonality, assist in generational succession, encouraging young people to stay in local agricultural production units and contributing to new technologies.

\section{Bibliographic Review}

In (Van der Ploeg's et al., 2000) rural development may seek a model for the agricultural sector that contemplates the production of public goods, such as the landscape, the valorization of scope economies to the detriment of economies of scale, the pluriactivity of rural families, the democratization of rural spaces. A combination of agricultural and non-agricultural activities carried out by residents in the family farming unit, where automated production processes may add to the achievement of better results, especially the so-called family farming.

In the conception of (Amer et al., 2015) robotics in agriculture has been tested in studies to develop harvesters for tomatoes, cherries, cucumbers, mushrooms and other fruits, with good results. Naik et al. (2016) present a robot for precision agriculture application that allows sowing with adequate depth and row spacing with good accuracy compared to manual processes. For (Valdiero, 2012), the productive, industrial, agro-forestry and agricultural equipment processes present good results. Otherwise, to (Dantan at al., 2013) studies a suspended robot for cleaning and sanitizing the inner surface of grain storage silos, designed to replace human labor in this risky and dangerous but necessary task.

Porsch et al. (2016) studied and developed an automatic platform tilt control module to maintain agricultural implements on sloping terrain, with real-time information recording, with potential applications of precision agriculture-oriented automation technologies, contemplating an integrated device methodology in the development of family farming machines.

The design of a pneumatically driven gantry robot for greenhouse vegetable sowing as a low cost alternative for increased productivity and ergonomic working conditions in the context of precision agriculture was also developed by (Porsch et al., 2017). Otherwise, concerned about the demand for more efficient machinery and seeking to reduce operating costs, (Santos et al., 2015) evaluated the operational performance of a fertilizer seeder as a function of the travel speed and the fertilizer furrower mechanism.

The works of (Ritter, 2010 and Porsch, 2012), illustrated in (Figure 1) show, in diagrammatic form, the nonlinearities included in the mathematical modeling for each gantry robot actuator (link) with precision agriculture application proposed in this work. 


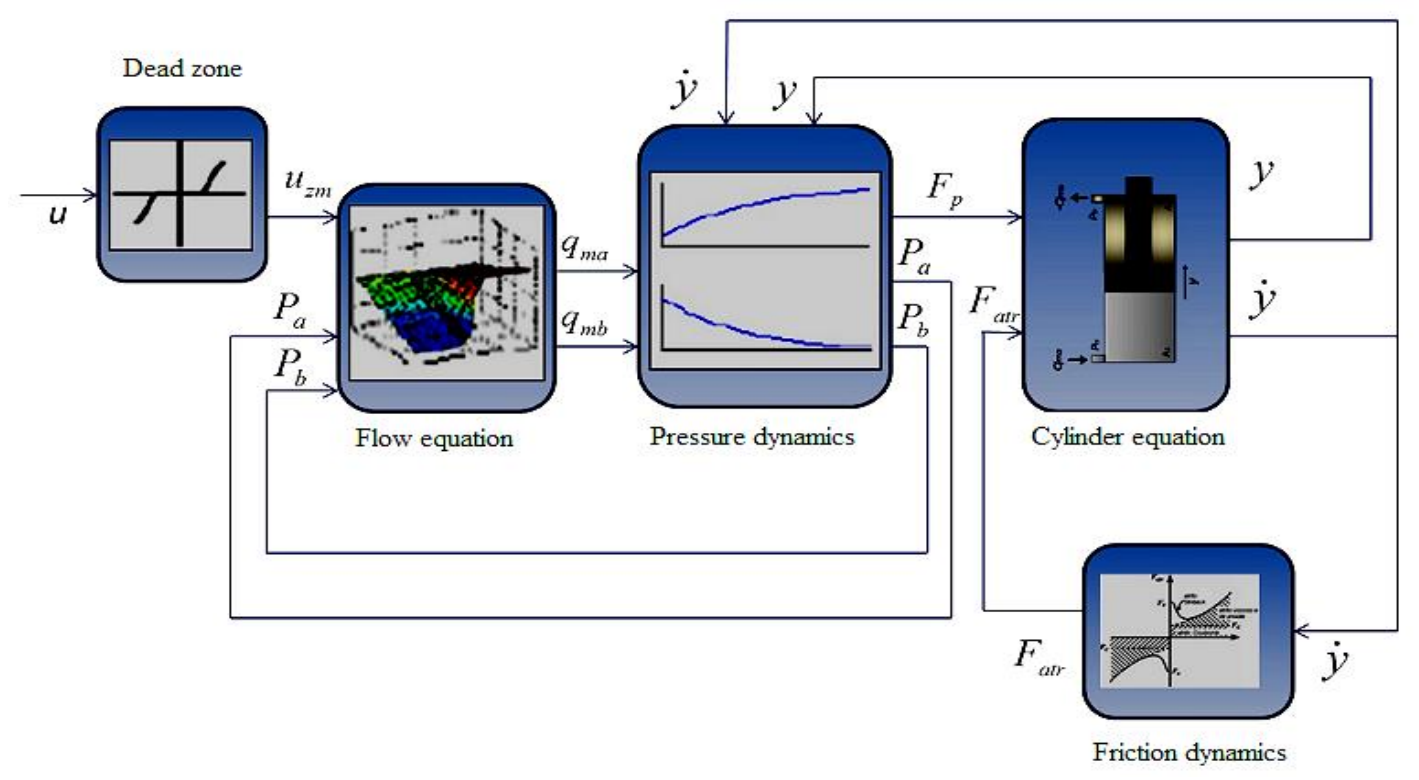

Figure 1. Nonlinearities included in the mathematical model for the Gantry Robot, adapted from Ritter (2010) and Porsch (2012)

From the control signal (u) represented by the first block, there is the second block that represents the nonlinearities found in the dead zone according to (Valdiero et al., 2008), because the width of the spool is greater than the width of the hole through which air passes under pressure in the servo valve.

The third block represents the pressure dynamics obtained from the continuity equation and results in two first-order nonlinear equations and thus the block representing the motion equation of the pneumatic actuators and finally the friction dynamics block, which is the factor that most affects the equation of motion and is a phenomenon difficult to describe analytically according to (Ritter et al., 2010; Porsch et al., 2011; Valdiero, 2012 and Richter et al., 2013).

Figure 2 shows the schematic cross-sectional drawing of the special double acting pneumatic cylinder prototype and self-guided cable type modeled and developed in this work.

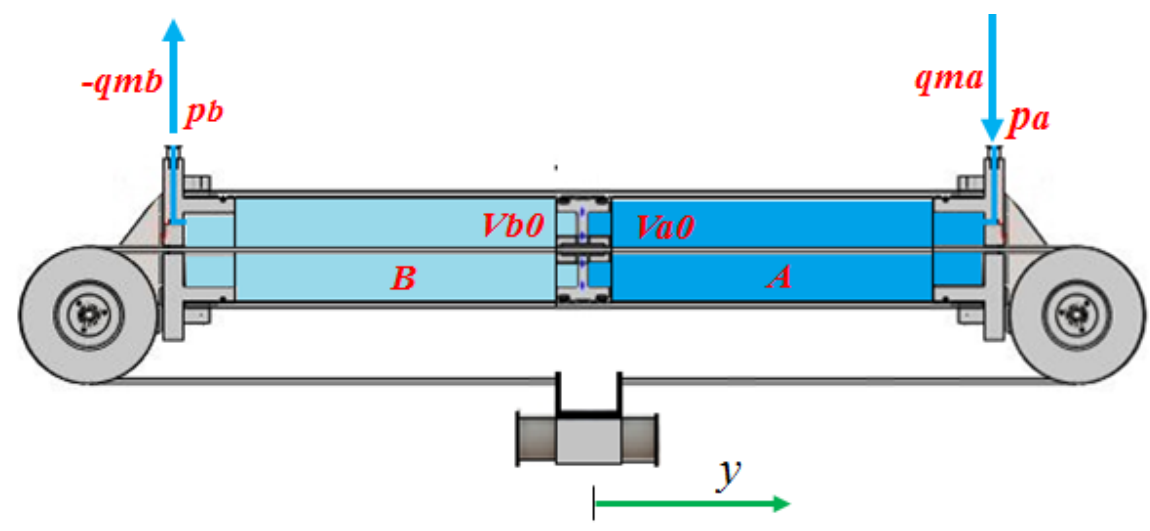

Figure 2. Schematic of the cross section of a guided cable cylinder 


\section{IIMacrothink}

To represent the dynamics of chamber pressures, the continuity equation is used, based on the principle of energy conservation according to (Perondi, 2002) given by (Equation 1) and (Equation 2).

$$
\begin{aligned}
& \dot{p}_{a}=-\frac{A_{1} \gamma \dot{y}}{A_{1} y+V_{a 0}} p_{a}+\frac{R \gamma T}{A_{1} y+V_{b 0}} q_{m a}\left(p_{a}, u\right) \\
& \dot{p}_{b}=\frac{A_{2} \gamma \dot{y}}{V_{b 0}-A_{2} y} p_{b}+\frac{R \gamma T}{V_{b 0}-A_{2} y} q_{m b}\left(p_{b}, u\right)
\end{aligned}
$$

Where $A_{1}$ and $A_{2}$ are the cross-sectional areas of chambers $\mathrm{A}$ and $\mathrm{B}$ of the cylinder, $q_{m a}$ and $q_{m b}$ are the mass flow rates in chambers $\mathrm{A}$ and $\mathrm{B}$, respectively. The supply air temperature is $\mathrm{T}$, and $\mathrm{R}$ is the universal constant of gases, $\gamma$ being the relationship between specific air heats, $V_{a 0}$ and $V_{b 0}$ the dead volumes in chambers A and B. The control voltage signal applied to the servo valve is $u$ for adjusting the position $y$ and $\dot{y}$ speed of the pressurized piston $p_{a}$ and $p_{b}$ in chambers A and B respectively.

In a pneumatic drive robot the joint torque $\tau$ is applied by actuators that have complex dynamics. The pneumatic actuator considered in the modeling is mainly composed of a 5-way spool proportional directional valve and a symmetrical double acting rodless pneumatic cylinder, as shown in (Figure 3). 


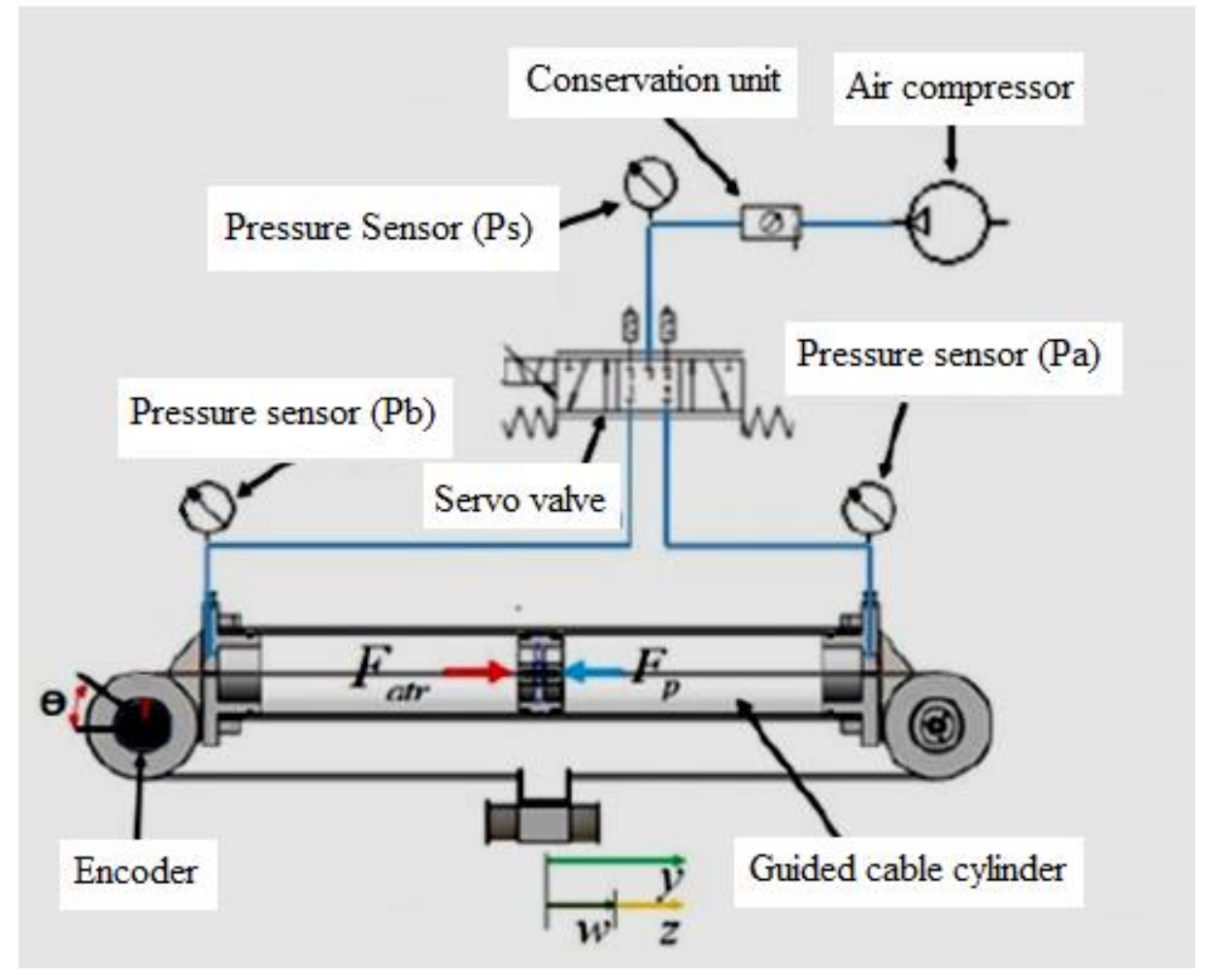

Figure 3. Schematic drawing of the pneumatic actuation system

The pneumatic system responsible for providing information to the controller and driving the cylinders consists of pressure sensors that inform the gauge pressure value in each of the cylinder chambers as well as the supply pressure. An air conditioning and treatment unit filters and allows the regulation of air pressure.

In addition to two 3-way 5-position servo valves that direct air flow to the cylinder, a proportional servo valve regulates compressed air flow, pressure and direction. The displacement of the valve spool is caused by a symmetrical signal voltage applied to the solenoid so that by displacing the servo valve spool in one direction, one chamber is connected to supply pressure and the other to atmospheric pressure.

\section{Materials and Method}

\subsection{Prototype and Test Bench Assembly}

The prototype was developed on a workbench available at UNIJUÍ Campus Panambi's Innovation Center for Automatic Machines and Servo Systems (NIMASS) and was subdivided into steps described from the needs analysis given by (Valdiero and Rasia, 2016).

The CAD (solidWorks) design of the pneumatically actuated gantry type cartesian robot mounted on the fixed structure of a greenhouse with three degrees of freedom with prismatic joints is shown in (Figure 4). 


\section{Macrothink}

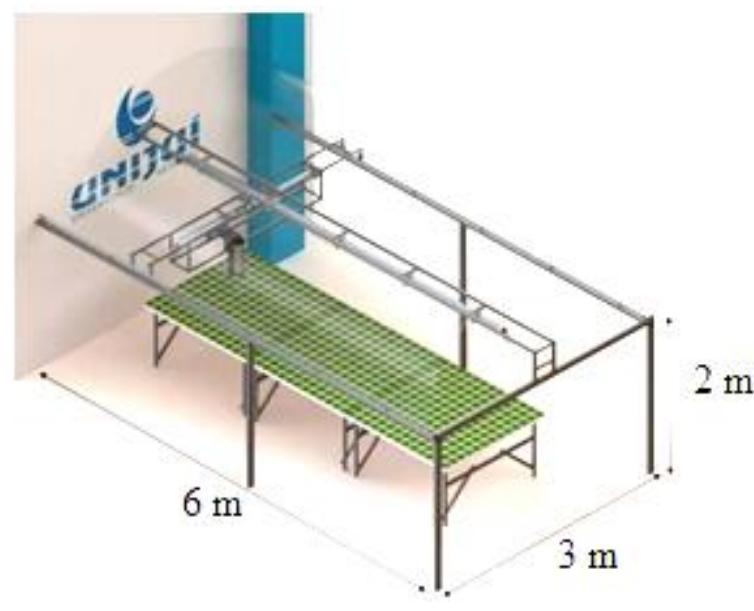

(a)

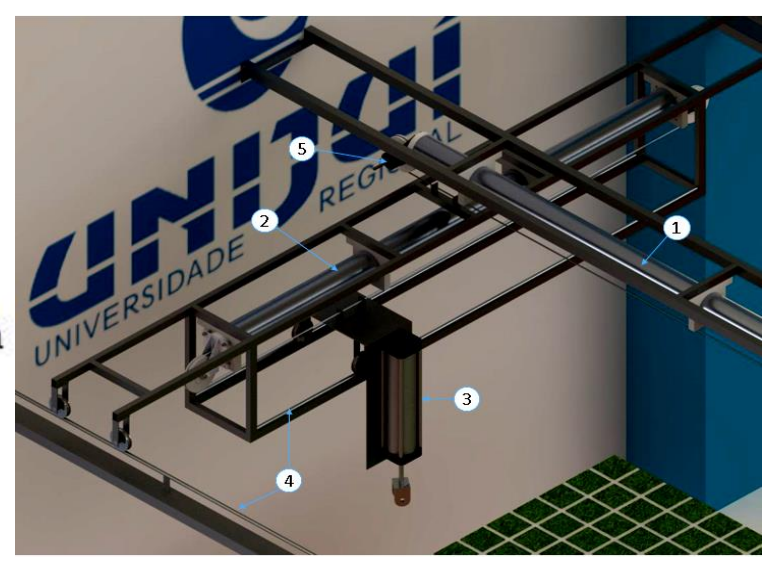

(b)

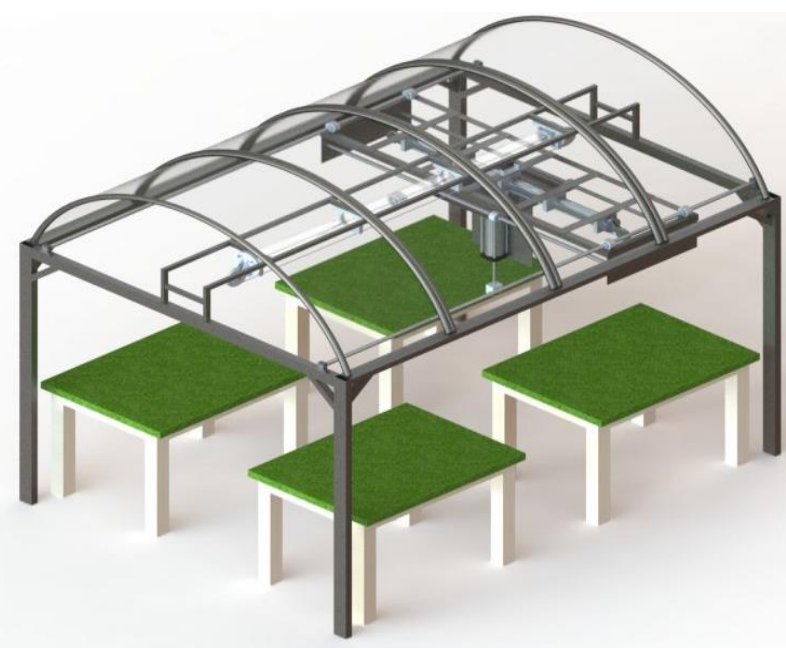

(c)

Figure 4. Gantry Robot Design with three degrees of freedom and pneumatic drive: (a) highlight to the robot structure; (b) robot mounted on the greenhouse structure indicating its main components and (c) iconic model of the greenhouse designed with the robotic manipulator inside

Agricultural greenhouses protect the plant and provide the plants with favorable conditions for growth, flowering and fruiting. Sowing and harvesting activities are generally carried out manually, which often results in non-ergonomic and stressful work.

The solutions available in the market meet the requirements of comfort and production, but the high cost of an automated greenhouse becomes unfeasible to the family farmer. Given this, in order to meet the needs of a potential customer, a prototype was developed that satisfies ergonomics, increased production, low cost of acquisition and environmental sustainability.

Table 1 shows the main components of the Gantry Greenhouse robot with numerical indications illustrated in (Figure $1 \mathrm{~b}$ ). 
Table 1. Prototype component specifications

\begin{tabular}{c|l}
\hline Item shown in (Figure 4b) & \multicolumn{1}{c}{ Component } \\
\hline$(1)$ & Rodless Cylinder (Guided Cable) \\
\hline$(2)$ & Rodless Cylinder (Guided Cable) \\
\hline$(3)$ & Single Acting Double Rod Cylinder \\
\hline$(4)$ & Guides \\
\hline$(5)$ & Encoder \\
\hline
\end{tabular}

The cylinder (1) is responsible for pulling a frame holding the cylinder (2), where this structure is guided by pulleys on a solid steel shaft.

The cylinder (3) is responsible for the sowing and harvesting operation whose final effectors, claw, can be adapted to the required tool for the activity to be performed in a particular horticulture.

An Incremental Encoder reads the pulses of a shaft attached to a pulley where a wire rope passes indicating the position the robot is in. This wire rope ends up pulling the structure that holds the cylinder (2).

Figure 5 illustrates the development of the first stage of the actuator responsible for the robot's first degree of freedom, showing details of the other constituent parts of the guided cable actuator.

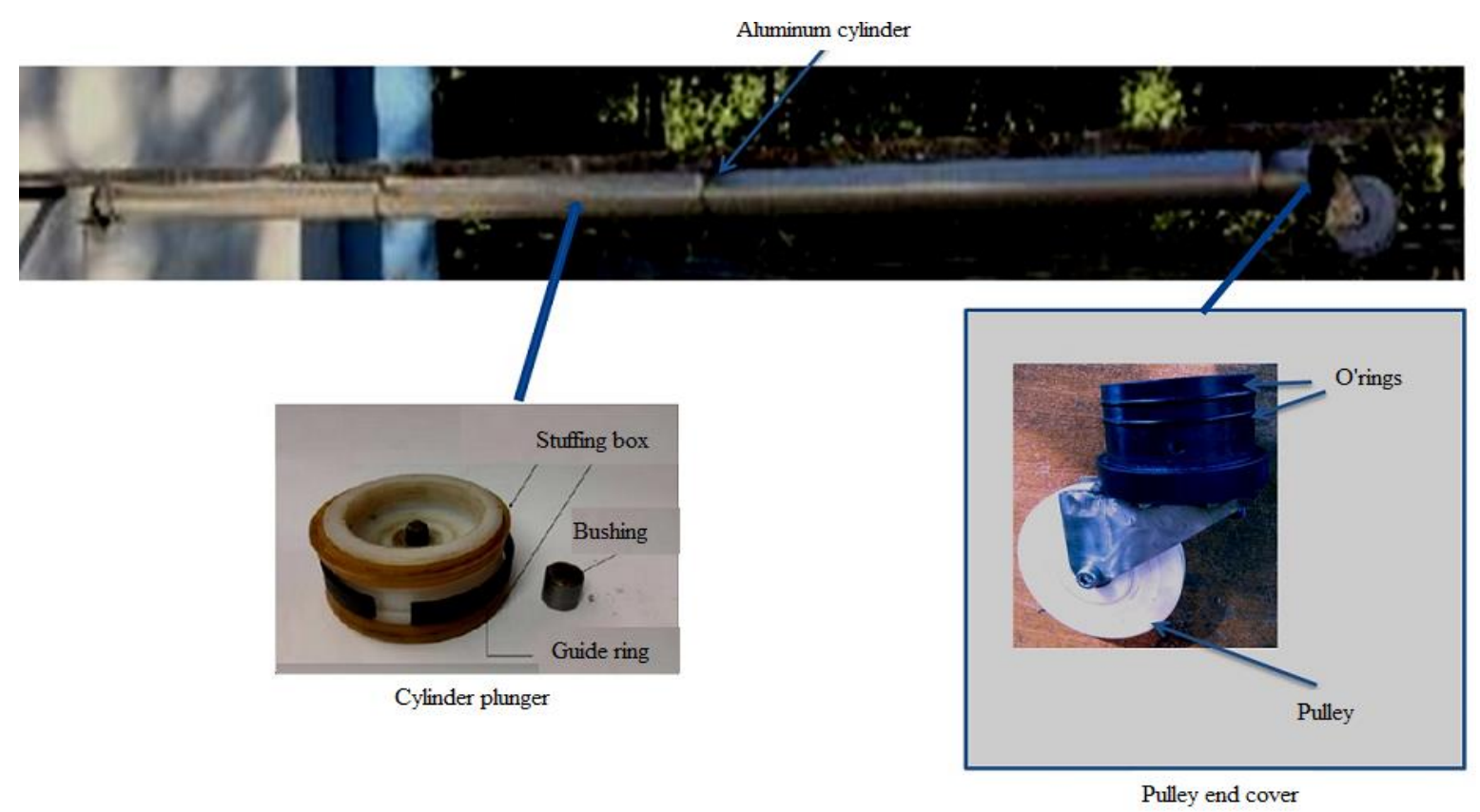

Figure 5. Components of the robot's first degree of freedom

For the construction of the cable-guided actuator, an aluminum circular tube with an inner diameter of $96 \mathrm{~mm}$, a length of $4700 \mathrm{~mm}$ and a wall thickness of $2 \mathrm{~mm}$ as shown in (Figure 5). 


\section{Macrothink}

Journal of Agricultural Studies

ISSN 2166-0379 2019, Vol. 7, No. 4

To seal the cylinder ends, nylon caps were machined. These caps have two slots for the placement of O-rings to seal. A threaded hole was drilled for the insertion of a pneumatic connection for the air passage to the cylinder chambers. In the center of the caps there is a $5 \mathrm{~mm}$ hole with an internal slot for placement of an O-ring, through which a wire rope goes through, the caps are secured to the cylinder by screws.

The developed cable-guided cylinder is coupled to the $96 \mathrm{~mm}$ piston by means of a wire rope, also machined, through a nut attached to the cable, inside a bushing, as shown in (Figure 6).
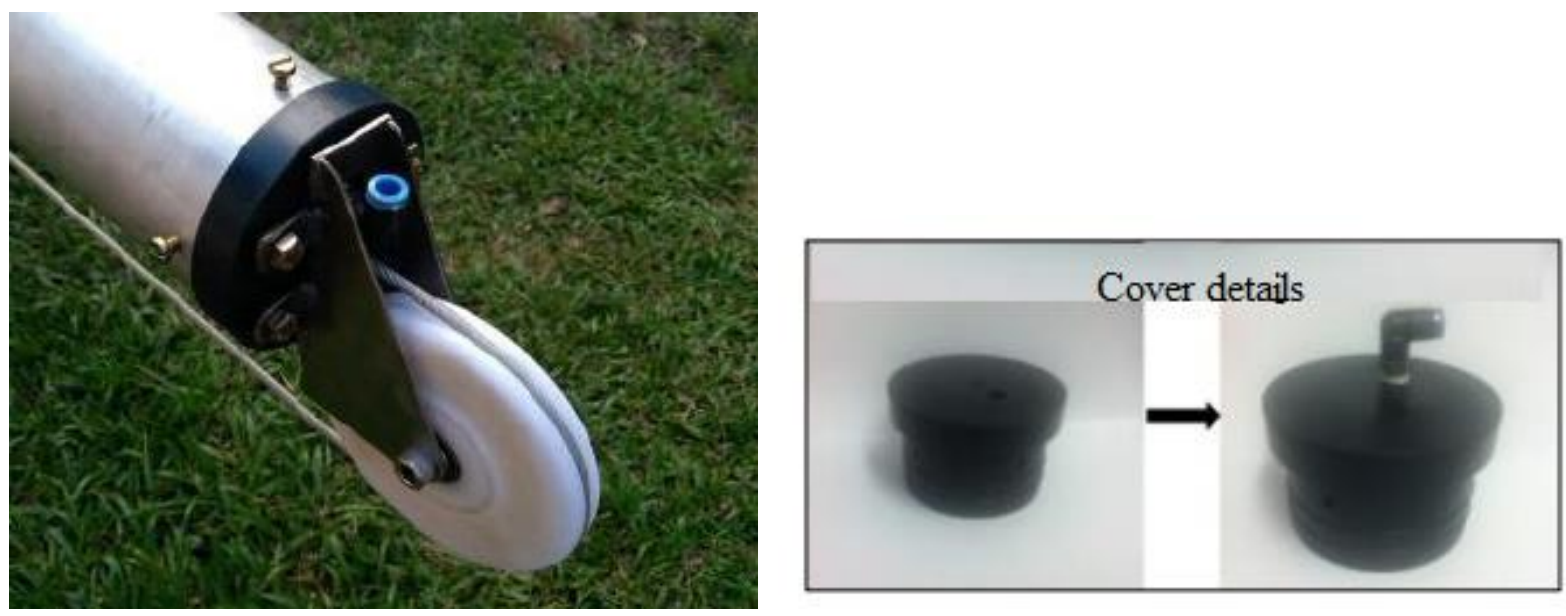

(a)

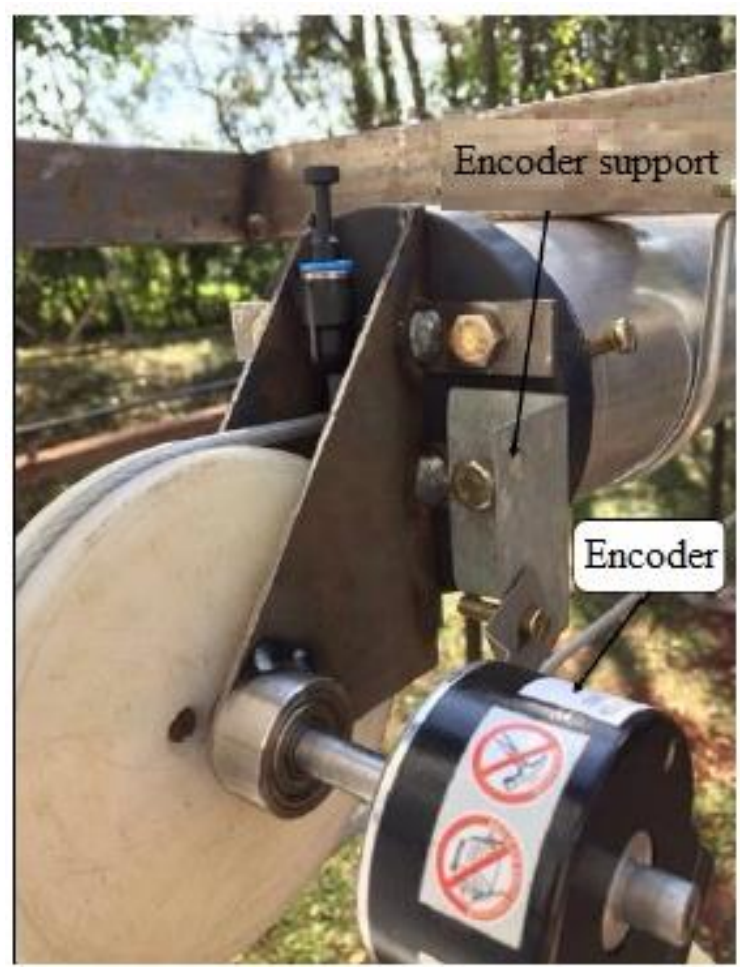

(b)

Figure 6. (a) Detail of coupled pulley cover, (b) Detail of coupled pulley cover and encoder coupled to the first degree of freedom system 


\section{Macrothink

The robot's second degree of freedom is shown in (Figure 7). For the construction of the cable-guided actuator, an aluminum circular tube with an inner diameter of $72.9 \mathrm{~mm}$, a length of $2600 \mathrm{~mm}$ and a wall thickness of $2 \mathrm{~mm}$ was used. The other items follow the same descriptions of the construction of the first degree of freedom.

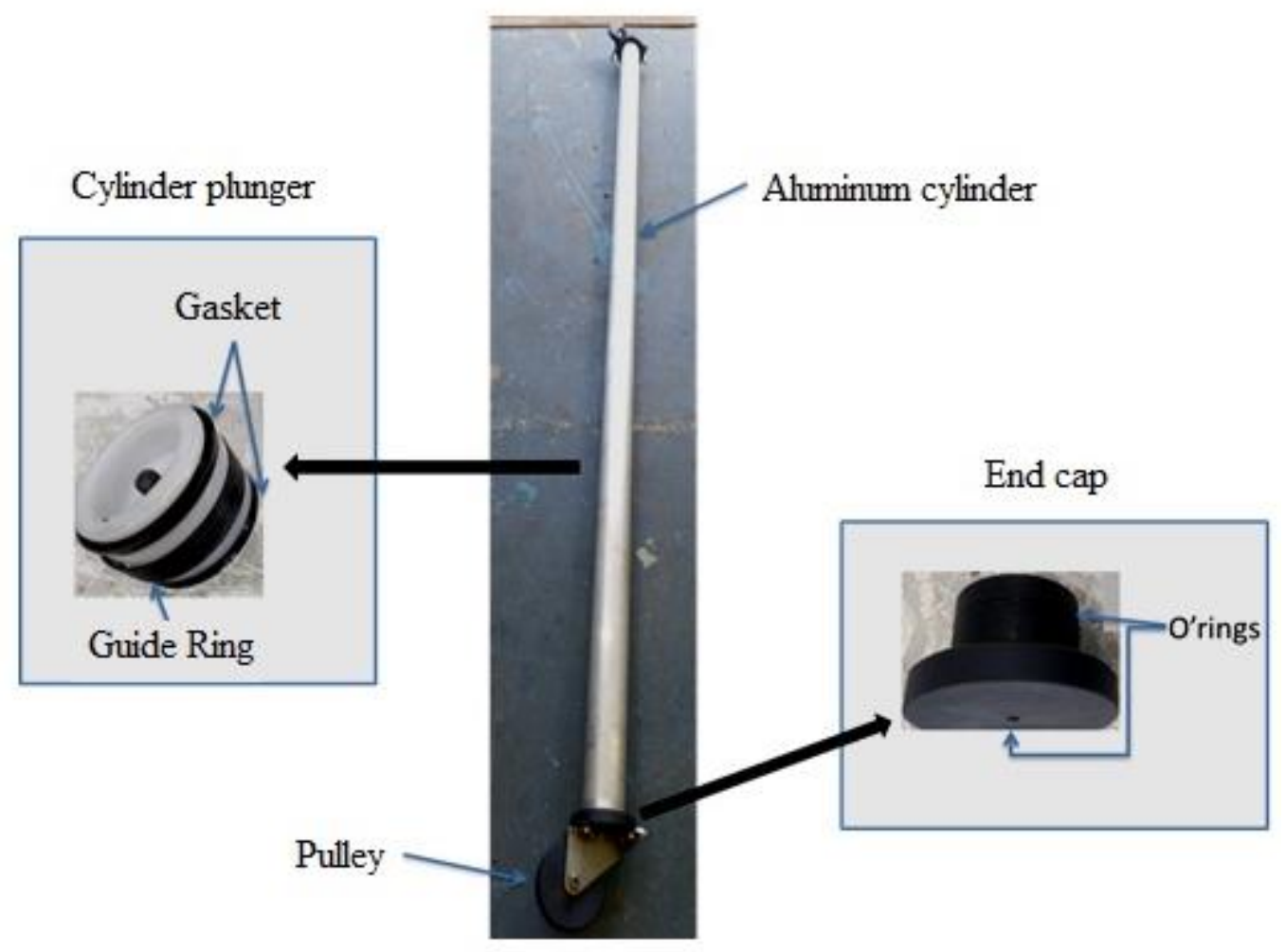

Figure 7. Robot High School Components

The displacements of the robot's prismatic joints are captured by a dSpace model 1104 electronic signal acquisition and control board mounted on a microcomputer using controldesk software. The Gantry robot is intended for use in tray seedling production tasks following spatial spacing requirements, ie in each tray cell and at the appropriate depth for each crop.

For the third degree of the robot, a double acting single rod pneumatic cylinder was used, item (3) of Table 1, whose actuator has a $400 \mathrm{~mm}$ stroke and a $20 \mathrm{~mm}$ diameter rod.

For the implementation of the control system, we used the MatLab/Simulink software whose programming was performed through block diagrams shown in (Figure 8). 


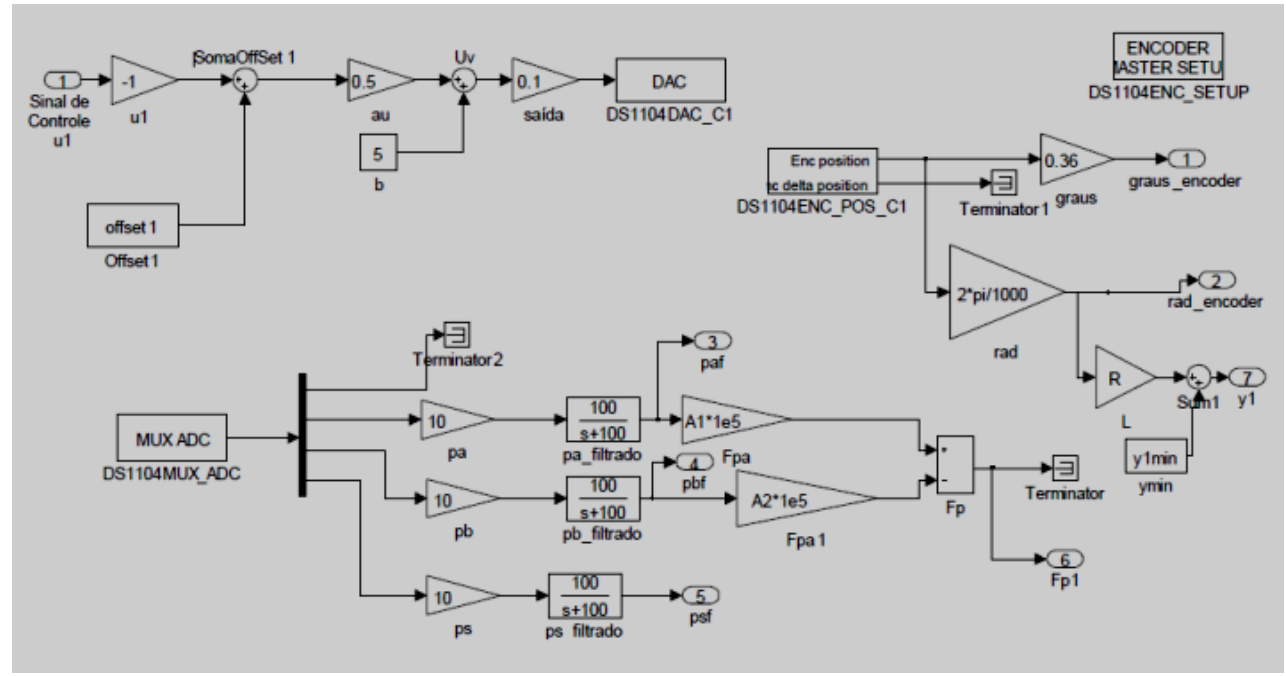

Figure 8. Gantry robot control block diagram

The control block diagram illustrated in (Figure 8) was developed with the servo valve dead zone compensation option according to (Valdiero, 2012).

\section{Results and Discussions}

Figure 9 illustrates the behavior of actuator 1 of the gantry robot experimental prototype for applications in agricultural greenhouses for an open loop $-4 \mathrm{~V}$ and $4 \mathrm{~V}$ step input signal. It has a graphical representation of the voltage as a function of time, the position as a function of time in the pressures in chamber A and B, as well as the supply pressure as a function of time and the pneumatic force as a function of time.
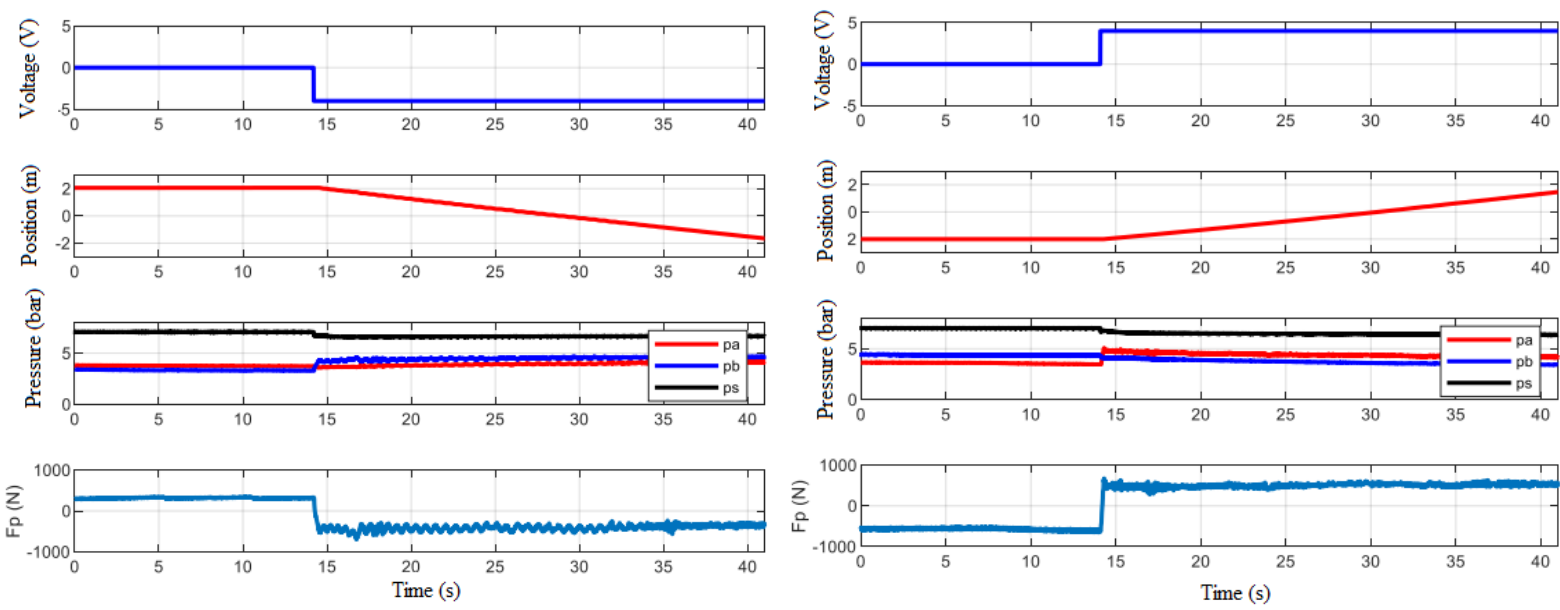

Figure 9. Graphics for open loop experimental cylinder 1 with $-4 \mathrm{~V}$ and $4 \mathrm{~V}$ control signal

The presented results show that the input signal voltage for actuator 1 was used step signal of $-4 \mathrm{~V}$ and $4 \mathrm{~V}$, respectively. This voltage energized the valve solenoid so that a resulting magnetic force was applied to the servo valve spool producing the spool displacement. Opening the control holes for chamber A and chamber B of the cylinder produced a pressure difference. The pressure difference is called pneumatic force, which moves the actuator 
piston inside the cylinder.

(Figure 9) shows the actuator piston movement, the supply pressure used was 7 bar. With the plunger set back at the start of stroke, position $2 \mathrm{~m}$, air is directed into chamber B, thereby increasing pressure, resulting in the resulting pneumatic force that moves the plunger into the cylinder to the stroke end, position $-2 \mathrm{~m}$. Similarly, when the $4 \mathrm{~V}$ signal is applied, the supply pressure is directed to the orifice of chamber A, causing a pressure difference and consequently the pneumatic force that moves the piston in the opposite direction from position $-2 \mathrm{~m}$ to position $2 \mathrm{~m}$.

Figure 10 presents the behavioral graphs of actuator 2 of the gantry robot experimental prototype for agricultural greenhouse applications for an open-loop step signal $-8 \mathrm{~V}$ and $8 \mathrm{~V}$. It shows the voltage versus time, position versus time, pressures in chamber A and B, as well as supply pressure versus time and pneumatic force versus time.
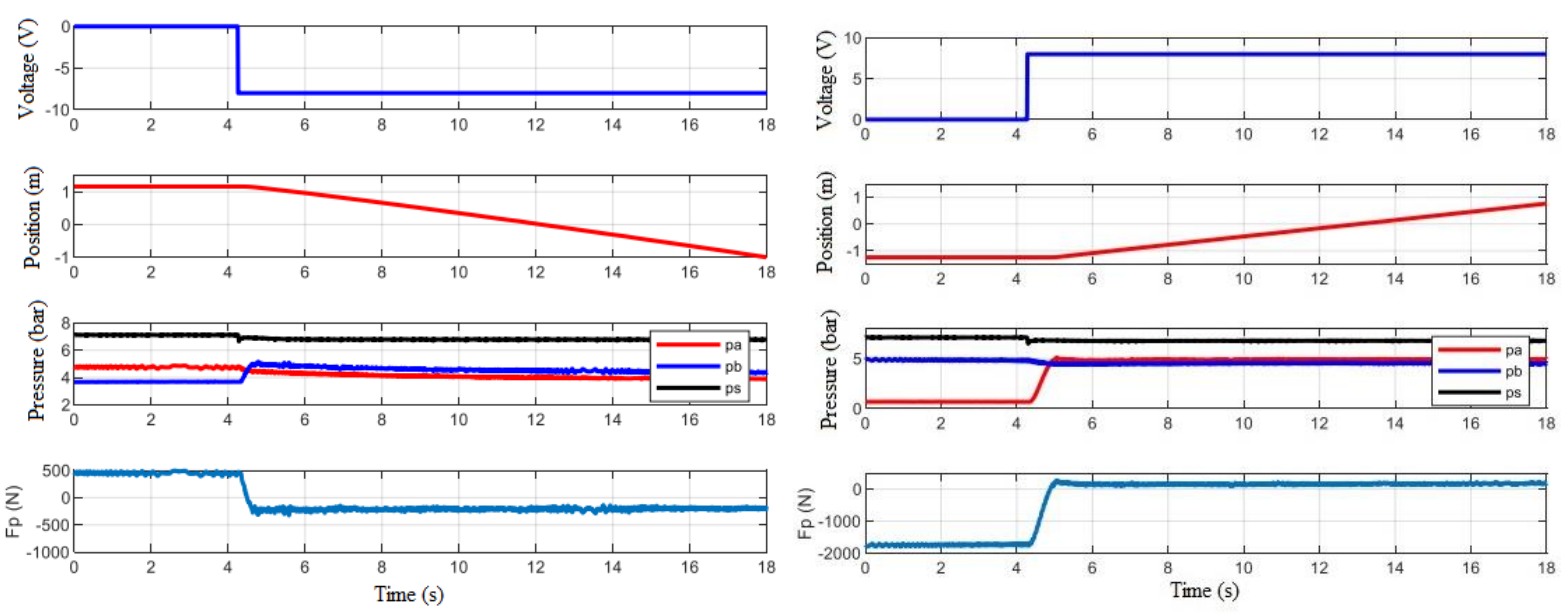

Figure 10. Graphics for open loop experimental cylinder 1 with $-8 \mathrm{~V}$ and $8 \mathrm{~V}$ control signal

The results shown in (Figure 10) show that the input signal voltage for actuator 2 was used -8 $\mathrm{V}$ and $8 \mathrm{~V}$ step signal, respectively. Similarly to actuator 1 , the supply pressure used was 7 bar. Thus with input signal at $-8 \mathrm{~V}$ and piston set back at stroke start, position $1.2 \mathrm{~m}$, air is directed to chamber $\mathrm{B}$, thereby increasing pressure, resulting in the resulting pneumatic force that moves the piston inside the cylinder to end of stroke, position $-1.2 \mathrm{~m}$. Similarly, when the $8 \mathrm{~V}$ signal is applied, the supply pressure is directed to the orifice of chamber A, causing a pressure difference and consequently the pneumatic force that moves the piston in the opposite direction from position $-1.2 \mathrm{~m}$ to position $1.2 \mathrm{~m}$.

The experimental results provide relevant data for position trajectory elaboration for the final robot effector applied to agricultural tasks in protected environment. The use of input signals with different values assists the dynamic system nonlinearity analysis test that makes position control in pneumatic actuators a difficult task, such as mass flow due to pressure difference and friction coefficients. 


\section{Conclusions}

The construction of the robotic manipulator prototype with two degrees of freedom used concepts of needs analysis, computer aided design projects, preliminary formulation of the direct and inverse kinematics equations and computational control system using materials available in our laboratory.

This work provided a series of experimental results such as pressure, pneumatic force and position control over time prior to the final construction of a fully autonomous machine for precision family farming tasks.

\section{Acknowledgement}

The authors thank FAPERGS and CNPq for financial assistance and UNIJUI for the laboratories.

\section{References}

Amer, G. S. M. M., \& Mudassir, A. M. M. (2015). Design and operation of Wi-Fi agribot integrated system, In:International Conference on Industrial Instrumentation and Control (ICIC). Pune, India, 207-212. https://doi.org/10.1109/IIC.2015.7150739

Auat, C. F. A., \& Carelli, R. (2013). Agricultural Robotics: Unmanned Robotic Service Units in Agricultural Tasks, In: IEEE Industrial Electronics Magazine, 7(3), 48-58. https://doi.org/10.1109/MIE.2013.2252957

Dantan, K., Ananiev, A., \& Kalaykov, I. (2013). SIRO: The silos surface cleaning robot concept, In: Proceedings of the IEEE International Conference on Mechatronics and Automation (ICMA).Takmatsu, Japan, 657-661. https://doi.org/10.1109/ICMA.2013.6617994

Eaton, R., Katupitiya J., Siew, K. W., \& Howarth, B. (2008). Autonomous Farming: Modeling and Control of Agricultural Machinery in a Unified Framework, 2008. 15th International Conference on Mechatronics and Machine Vision in Practice, Auckland, 499-504. https://doi.org/10.1109/MMVIP.2008.4749583

Escher, F., Schneider, S., Scarton, L. M., \& Conterato, M. A. (2014). Caracterização da Pluriatividade e dos Plurirrendimentos da Agricultura Brasileira a partir do Censo Agropecuário 2006. Revista de Economia \& Sociologia Rural [online], Piracicaba, 52(04), 643-668. https://doi.org/10.1590/S0103-20032014000400002

Naik, N. S., Shete V. V., \& Danve, S. R. (2016). Precision agriculture robot for seeding function, In: International Conference on Inventive Computation Technologies (ICICT), Coimbatore, 1-3. https://doi.org/10.1109/INVENTIVE.2016.7824880

Perondi, E. A. (2002). Controle não linear em cascata de um servoatuador pneumático com compensação do atrito. Tese (Doutorado em Engenharia Mecânica) - Programa de Pós-graduação em Engenharia Mecânica, Universidade Federal de Santa Catarina, Florianópolis. [Online] Available: https://lume.ufrgs.br/handle/10183/170153.

Porsch, M. R. M. H. (2012). Modelagem Matemática e Controle Proporcional de uma 
Bancada Acionada Pneumaticamente para Simulação de Terrenos Inclinados. 83 f. Dissertação (Mestrado em Modelagem Matemática) - Universidade Regional do Noroeste do Estado do Rio grande do Sul, Ijuí. [Online] Available: https://doi.org/10.5540/DINCON.2011.001.1.0172

Porsch, M. R. M. H., KlevestonL, O. L., Lopes, C. R., Rasia, A., \& Valdiero, A. C. (2016). Projeto de um módulo de comando e geogerenciamento para controle automático de inclinação em máquinas agrícolas. In: David Luciano Rosalen; Carlos Eduardo Angeli Furlani; Rogério Teixeira de Fari. (Org.). Novas tecnologias e inovações na Engenharia Agrícola. 1ed. Jaboticabal: SBEA, 1, 10-19. [Online] Available: http://publicacoes.conbea.org.br/livros/busca/?pagina=3

Porsch, M. R. M. H., Valdiero, A. C., Kinalski, N. M., Fiegenbaum, A., \& Rasia, L. A. (2017) Projeto de um robô gantry com acionamento pneumático para semeadura de hortaliças em estufa. In: Rosalen, D.L.; Silva, R.P. da; Turco, J.E.P. (Org.). Novas tecnologias e inovações na Engenharia Agrícola. 1ed. Jaboticabal: SBEA, 3, 111-120. [Online] Available: http://publicacoes.conbea.org.br/livros

Richter, R. R. M. (2013). Modelagem Matemática e Controle de Posição de um Atuador Linear Acionado Pneumaticamente. Dissertação (Mestrado em Modelagem Matemática) Universidade Regional do Noroeste do Estado do Rio Grande do Sul, Ijuí. [Online] Available: http://bibliodigital.unijui.edu.br:8080/xmlui/handle/123456789/1826?show=full

Ritter, C. S. (2010). Modelagem matemática das características não lineares de atuadores pneumáticos. 90 f. Dissertação (Mestrado em Modelagem Matemática) - Universidade Regional do Noroeste do Estado do Rio Grande do Sul, Ijuí. [Online] Available: http://bibliodigital.unijui.edu.br:8080/xmlui/handle/123456789/227

Santos, P. R. A., Chioderoli, C. A., Monteiro, L. A., Nicolau, F. E. A., \& Queiroz, R. F. (2015) Demanda energética de uma semeadora-adubadora com dois mecanismos sulcadores de fertilizantes sob três velocidades de deslocamento. In: XLIV Congresso Brasileiro de Engenharia Agrícola - CONBEA 2015, Novas tecnologias e inovações na Engenharia Agrícola: SBEA, 1, 1-4. [Online] Available:

http://publicacoes.conbea.org.br/anais/busca/?pagina=1\&ano=2015\&categoria=7\&opcoes=Sa ntos

Valdiero, A. C. (2012). Modelagem matemática de robôs hidráulicos In.: Coleção Modelagem Matemática Aplicada à Resolução de Problemas nas Engenharias. P. 200. UNIJUI, Ijuí. https://www.editoraunijui.com.br/produto/1849

Valdiero, A. C., \& Rasia, L. A. (2016). Gestão de projetos de pesquisa e desenvolvimento de produtos mecatrônicos In: Desafios em engenharia industrial.1 ed. Ijuí: UNIJUí, 1, 89-106. http://www.editoraunijui.com.br

Van der Ploeg, J. D., Renting, H., Brunori, G., Knickel, K., Marsden, T., de Roest, C., \& Ventura, F. (2000). Desenvolvimento rural: De práticas e políticas para teoria. Sociologia Ruralis 40(4), 391-408. Reino Unido: Editores Blackwel. 
https://doi.org/10.1111/1467-9523.00156

Yang, L., Noguchi, N., \& Takai, R. (2016). Development and application of a wheel-type robot tractor. Engineering in Agriculture, Environment and Food, 9(2), 131-140. https://doi.org/10.1016/j.eaef.2016.04.003

\section{Copyright Disclaimer}

Copyright for this article is retained by the author(s), with first publication rights granted to the journal.

This is an open-access article distributed under the terms and conditions of the Creative Commons Attribution license (http://creativecommons.org/licenses/by/4.0/). 